\title{
CHEMERIN BLOOD LEVELS ARE ASSOCIATED WITH MRI MEASURED VOLUMES OF ABDOMINAL ADIPOSE TISSUE COMPARTMENTS AND LIFESTYLE CHOICES
}

\author{
Tamer Salha ${ }^{1}$, David Andrijević ${ }^{2}$ Zvonimir Vrselja ${ }^{3}$, Vatroslav Šerić, \\ Radivoje Radic ${ }^{5}$ and Goran Curic ${ }^{6}$ \\ ${ }^{1}$ Department of Radiology, Osijek University Hospital Centre, Osijek, Croatia; \\ ${ }^{2}$ School of Medicine, Josip Juraj Strossmayer University of Osijek, Osijek, Croatia; \\ ${ }^{3}$ Department of Neuroscience, Yale School of Medicine, New Haven, CT, USA; \\ ${ }^{4}$ Department of Medical Biochemistry, Osijek University Hospital Centre, Osijek, Croatia; \\ ${ }^{5}$ Department of Anatomy and Neuroscience, School of Medicine, Josip Juraj Strossmayer University of Osijek, \\ Osijek, Croatia; ${ }^{6}$ Institute of Forensic Medicine, University of Bonn, Bonn, Germany
}

\begin{abstract}
SUMMARY - Obesity is a low-grade chronic inflammatory state, in which a cytokine chemerin with its immunometabolic modulation has an important role. We aimed to study in a healthy population relationships between serum chemerin levels, lifestyle choices and magnetic resonance imaging (MRI) assessed volumes of abdominal visceral (VAT) and subcutaneous (SAT) adipose tissues, which have different cytokine expression profiles. Overall, 73 healthy participants undertook lifestyle questionnaire and underwent anthropometric measurements along with MRI scanning of abdominal SAT and VAT. Furthermore, complete blood count was determined along with chemerin and fibrinogen serum levels. Regression model for prediction of chemerin serum levels was built after controlling for sex, age and anthropometric measures. Median serum chemerin was 141 (125-195) ng/mL. Serum chemerin had a moderate positive correlation with SAT and VAT volumes. The two most important predictors of chemerin levels were MRI detected SAT and thigh circumference. Independently, chemerin levels were associated with smoking, preference of salty food, and favoring flavor/simplicity of preparation over nutritional value of the food. Serum chemerin seems to be more strongly correlated with the volume of abdominal SAT than VAT, with certain lifestyle choices influencing chemerin levels independently of abdominal fat.
\end{abstract}

Key words: Obesity; Cytokines - blood; Magnetic resonance imaging; Fibrinogen; Abdominal fat; Adipokines; Intra-abdominal fat; Lifestyle; Smoking

\section{Introduction}

Obesity is recognized as a low-grade chronic inflammatory state. It is associated with increased mortality and numerous morbidities including metabolic

Correspondence to: Tamer Salha, MD, Department of Radiology, Osijek University Hospital Centre, J. Huttlera 4, HR-31000 Osijek, Croatia

E-mail: tsalha007@gmail.com

Received September 19, 2017, accepted October 25, 2017 syndrome, diabetes mellitus type 2 and coronary artery disease ${ }^{1,2}$. Adipose tissue (AT) secretes immunometabolic modulators called adipokines. Excessive AT has altered secretion profile, where several adipokines (or their lack) contribute to the pathophysiology of these comorbid diseases ${ }^{3,4}$. One such molecule secreted by $\mathrm{AT}$ is chemerin, also known as retinoic acid receptor responder protein 2 (RARRES2) ${ }^{5}$. As a potent signaling molecule, chemerin has been described as adipokine, cytokine, paracrine/autocrine hormone, tu- 
mor-suppressor, anti-microbiological and angiogenic agent $t^{5}$.

The primary production sites of chemerin in the body are the liver and adipose tissue; it is also expressed at lower concentrations in the pancreas and adrenal gland $^{6}$. It is known that chemerin is a ligand of three receptors: chemokine-like receptor 1 (CMLKR1), G-protein coupled receptor 1 (GPR1) and chemokine (C-C motif) receptor-like 2 (CCRL2). The most widely studied has been signaling through CMLKR1, while the roles of GPR1 and CCRL2 mostly remain to be elucidated, with the latter probably lacking intracellular signaling cascade ${ }^{7,8}$. CMLKR1 is expressed in various tissues, with highest expression in several inflammatory (spleen, placenta and lymph nodes) and non-inflammatory related sites (vena cava, lungs and urinary bladder) ${ }^{9,10}$. CMLKR1 expression profile is notably high in dendritic cells and macrophages ${ }^{7,8}$.

Chemerin regulates lipid metabolism and mesenchymal stem cell adipogenesis through autocrine/paracrine mechanisms ${ }^{11,12}$. Lack of chemerin or CMLKR1 expression in vitro abrogates adipogenesis, and modifies the expression of genes important in glucose and lipid metabolism, including glucose transporter type 4 (GLUT4), leptin and adiponectin ${ }^{13}$. Higher chemerin expression in AT is associated with metabolic syndrome and its metabolic disturbances ${ }^{14}$. Furthermore, chemerin mediates infiltration of macrophages in AT, and these are considered to be crucial cells in inflammatory activation of adipocytes in obesity ${ }^{13,15}$.

Morbidity/mortality risk is higher for abdominal than for overall obesity. Overall abdominal fat is a sum of subcutaneous (SAT) and visceral (VAT) adipose tissue, the latter consisting mainly of mesenteric, omental and retroperitoneal fat tissue ${ }^{16}$. Ibrahim et al. ${ }^{17}$ have shown that, in comparison to SAT, VAT contains higher amounts of inflammatory immune cells and greater number of large adipocytes, and that its preadipocytes have a weaker capacity to differentiate. Furthermore, VAT adipocytes are more insulin resistant, more metabolically active, and secrete a larger number of cytokines. Correlation of metabolic risk factors (increased body mass index (BMI), triacylglyceride, glucose, blood pressure, $\mathrm{C}$-reactive protein (CRP) and decreased high density lipoprotein) with SAT and VAT has already been established, with the latter showing stronger correlation ${ }^{18}$. Furthermore, VAT correlates to a greater extent with metabolic risk factors in women ${ }^{18}$. Alfadda et al. ${ }^{19}$ in a study of overweight subjects $\left(\mathrm{BMI}>25 \mathrm{~kg} / \mathrm{m}^{2}\right)$ did not establish difference in serum chemerin level between metabolically healthy (had fewer than two above mentioned metabolic risk factors) and metabolically unhealthy obese.

Chemerin mRNA expression in VAT and SAT in lean individuals was significantly lower than in obese patients, but did not differ in the expression levels between VAT and SAT ${ }^{20}$. This suggested that correlation between chemerin and BMI was only due to the increase in fat mass. On the contrary, mRNA chemerin expression in patients with type 2 diabetes mellitus and obese subjects was higher in VAT than in $\mathrm{SAT}^{9}$. A recent large study by Zylla et al. ${ }^{21}$ established the association between AT volumes, inflammation markers and chemerin levels.

As distribution of AT is of a well-known importance (i.e. for cardiovascular disease), there are numerous attempts to directly, through imaging techniques, or indirectly (i.e. using different anthropometric measures) assess the quantity of AT in different depots. Assessment of SAT and VAT by magnetic resonance imaging (MRI) or computed tomography (CT) and post mortem assessment correlated well ${ }^{22}$. Anthropometric measures showed positive correlations with post mortem AT volumes only in certain study groups (i.e. quantity of VAT measured by MRI $(20 \mathrm{~cm}$ above and $10 \mathrm{~cm}$ below the L4 and L5 intervertebral disk) in obese subjects (BMI 30.0 to $39.9 \mathrm{~kg} / \mathrm{m}^{2}$ ), and positive correlation with waist circumference (WC) and waisthip ratio (WHR) only in females) ${ }^{23}$.

Only a few studies have investigated the relationship between AT volumes and blood chemerin ${ }^{21,24}$. Metabolic disturbances do not appear only among obese individuals (i.e. normal-weight obesity syndrome), and the knowledge about the underlying molecular and environmental mechanisms is rather scarce. Due to the association of chemerin with metabolic disturbances ${ }^{13,15}$, it would be of interest to get an insight into the effect of environmental factors (i.e. diet, physical activity) on chemerin level and body fat distribution in a healthy, non-obese population. Moreover, it would be valuable to study long-term effects of these 'lifestyle' factors. In order to answer some of these questions, we studied relationships between chemerin, dietary/lifestyle habits and volumes of abdominal VAT and SAT in a cross-sectional manner in a healthy, non-obese population. 
The goals of this study were to establish (1) relationship between chemerin serum levels and adipose tissue volumes of abdominal region; (2) to compare anthropometric measures to MRI acquired parameters in chemerin serum level prediction; and (3) to explore how certain lifestyle and dietary habits influence chemerin serum levels in a healthy, adult population.

\section{Patients and Methods}

\section{Physical examination, laboratory blood tests and health/habits/lifestyle questionnaire}

The study was approved by the local ethics committee and all persons gave their informed consent prior to their inclusion in the study. The sample consisted of 73 healthy Caucasians (34 females), recruited volunteers and students from the School of Medicine, University of Osijek, Croatia. Medical history was taken in each subject and only those without prior medical conditions were included in the study. The median age of the participants was 24 (21-33) years. Physical examination included anthropometry (weight, height, WC at the level of umbilicus, hip circumference at the level of greater trochanters, thigh circumference at the middle third of the thigh, triceps skinfold thickness at the middle third of the upper arm, and subscapular skinfold thickness (SST)), vital signs check (blood pressure), and laboratory blood tests (complete blood count, fibrinogen, chemerin). All participants undertook a questionnaire assessing lifestyle and eating habits. The mean arterial pressure (MAP) was calculated as the sum of diastolic blood pressure and one-third of systolic blood pressure.VAT/ SAT is the ratio of abdominal VAT volume to SAT volume. BMI was defined as the ratio of weight in kilograms to squared height in meters.

\section{MRI}

The SAT and VAT were measured with MRI (Siemens Magnet Avanto 1.5T MRI System, DMS Health Technologies, ND, USA), using standardized T1 'fast spin echo' sequence for measuring AT. The abdominal region of interest was from the upper liver edge to the pubic symphysis. AT volume calculation was based on approximately 20 slices per participant. The program used for analyzing MRI images was open-source ImageJ. Adipose tissue was distinguished using intensity threshold macro-program, which made pictures binary, leaving only those intensities above curtain cut off value. On each slab, surface area of SAT and VAT was manually measured using the region of interest principal. The volume of AT was calculated according to the MRI parameters, multiplying surface area of adipose tissue on each slab with slab thickness and corresponding distance between the measured slab and subsequent one. MRI acquisition and post processing was done by a radiologist with more than 10 years of experience in MRI body imaging.

\section{Chemerin ELISA}

Chemerin was quantified using human chemerin enzyme-linked immunosorbent assay (ELISA) kit (Enzo Life Sciences, Farmingdale, NY, USA). Blood sampling was performed early in the morning on an empty stomach, after less than 12-hour fasting.

\section{Statistics}

Values are presented as median [Q1-Q3] or mean $( \pm \mathrm{SD})$ depending on the distribution. Distribution of variables was tested using Shapiro-Wilk test. Normally distributed variables were compared using parametric Student's t-test and one-way ANOVA. Variables that were not normally distributed were compared using nonparametric Mann-Whitney and Kruskal-Wallis tests. In order to perform relationship analyses, Pearson correlation and multiple regression analysis with forward stepwise method of fitting were used. Prior to regression model building, independent predictor variables were screened for multicolinearity and singularity. A two-sided $\mathrm{p}<0.05$ was considered significant. IBM SPSS Statistica v. 15.0 was used on statistical analyses.

\section{Results}

The overall descriptive results of the study participants are shown in Table 1. Chemerin blood levels correlated with VAT and SAT volume $(\mathrm{r}=0.419$, $\mathrm{p}<0.001$; and $\mathrm{r}=0.482, \mathrm{p}<0.001$, respectively) (Fig. 1B and $1 \mathrm{C})$, subscapular skinfold thickness and $\mathrm{WC}$ $(r=0.364, p=0.009$, and $r=0.289, p=0.036$, respectively). Other classical anthropometric measures did not correlate (data not shown). Among analyzed blood parameters, chemerin blood levels showed a moderately 
Table 1. Descriptive results of study participants $(N=73)$ for all participants with additional stratification according to gender

\begin{tabular}{|c|c|c|c|c|}
\hline \multirow{2}{*}{ Anthropometry } & \multirow[b]{2}{*}{ Age (yrs) } & \multirow{2}{*}{$\begin{array}{l}\text { Overall } \\
24(21-33)\end{array}$} & \multirow{2}{*}{$\begin{array}{l}\text { Female } \\
21(21-29)\end{array}$} & \multirow{2}{*}{\begin{tabular}{|l|} 
Male \\
$30(21-38)$
\end{tabular}} \\
\hline & & & & \\
\hline & Height $(\mathrm{cm})$ & $176(167-183)$ & $168(163-173)$ & $182(176-187)$ \\
\hline & Weight (kg) & $76(61-89)$ & $63(56-68)$ & $88(70-98)$ \\
\hline & Body mass index $\left(\mathrm{kg} / \mathrm{m}^{2}\right)$ & $24.0(21.4-27.0)$ & $21.7(20.5-23.3)$ & $26.0(24.9-29.1)$ \\
\hline & Waist circumference $(\mathrm{cm})$ & $84(72-94)$ & $72(67-79)$ & $94(86-106)$ \\
\hline & Hip circumference $(\mathrm{cm})$ & $95(89-102)$ & $90(86-93)$ & $100(95-106)$ \\
\hline & Thigh circumference $(\mathrm{cm})$ & $52(49-56)$ & $49(46-52)$ & $55(52-58)$ \\
\hline & Triceps skinfold thickness (mm) & $16(14-20)$ & $17(14-20)$ & $16(12-22)$ \\
\hline & Subscapular skinfold thickness (mm) & $16(12-24)$ & $13(10-16)$ & $23(14-29)$ \\
\hline & Mean arterial pressure (mm Hg) & $92(83-100)$ & $87(80-97)$ & $94(88-105)$ \\
\hline \multirow[t]{3}{*}{ MRI } & SAT (L) & $3.37(2.61-4.47)$ & $3.32(2.37-4.14)$ & $3.61(2.75-5.71)$ \\
\hline & VAT (L) & $1.25(0.74-2.32)$ & $0.83(0.58-1.12)$ & $2.20(1.27-3.12)$ \\
\hline & VAT/SAT & $0.37(0.24-0.59)$ & $0.24(0.19-0.32)$ & $0.57(0.40-0.65)$ \\
\hline ELISA & Chemerin (ng/mL) & $141(125-195)$ & $137(124-192)$ & $154(131-195)$ \\
\hline \multirow[t]{9}{*}{ Blood work } & Red blood cells (x10²/L) & $4.7(4.3-5.2)$ & $4.3(4.1-4.6)$ & $5.1(4.7-5.2)$ \\
\hline & Hemoglobin (g/L) & $138(129-152)$ & $130(123-135)$ & $151(144-158)$ \\
\hline & Hematocrit (\%) & $41(39-45)$ & $39(37-40)$ & $44(42-46)$ \\
\hline & MCV (fL) & $88(86-91)$ & $89(87-93)$ & $86(84-89)$ \\
\hline & $\mathrm{MCH}(\mathrm{pg})$ & $30(29-31)$ & $30(28-30)$ & $30(29-31)$ \\
\hline & $\mathrm{MCHC}(\mathrm{g} / \mathrm{L})$ & $333(325-345)$ & $326(323-338)$ & $342(331-350)$ \\
\hline & Platelets (x10\%/L) & $233(208-276)$ & $255(217-287)$ & $220(193-259)$ \\
\hline & Fibrinogen $(\mathrm{g} / \mathrm{L})$ & $3(2.5-3.4)$ & $3(2.5-3.4)$ & $2.9(2.5-3.6)$ \\
\hline & White blood cells $\left(x 10^{9} / \mathrm{L}\right)$ & $6.4(5.5-7.3)$ & $6.5(5.8-7.3)$ & $6.2(5.4-7.3)$ \\
\hline
\end{tabular}

Results are shown as median (Q1-Q3); MRI = magnetic resonance imaging; ELISA = enzyme-linked immunosorbent assay; SAT = subcutaneous adipose tissue; $\mathrm{VAT}=$ visceral adipose tissue; $\mathrm{MCV}=$ mean corpuscular volume; $\mathrm{MCH}=$ mean corpuscular hemoglobin; $\mathrm{MCHC}$ $=$ mean corpuscular hemoglobin concentration.

strong positive correlation with fibrinogen levels $(\mathrm{r}=0.403, \mathrm{p}=0.004)$, whereas mean corpuscular volume $(\mathrm{MCV})$ showed a weak negative correlation $(\mathrm{r}=-0.284$, $\mathrm{p}=0.036$ ), and other parameters did not correlate with chemerin. Fibrinogen blood levels had a weak positive correlation with SAT volume $(\mathrm{p}=0.047)$, but not with VAT volume ( $\mathrm{p}=0.074$ ) (Fig. $1 \mathrm{E}$ and $1 \mathrm{~F}$ ).

To predict chemerin serum levels, a stepwise regression model was employed with MRI measured adipose tissue volumes, anthropometric measures, complete blood count and fibrinogen levels as independent predictors controlled for age and sex. The final model explained $40.6 \%$ of variance in chemerin serum levels and included the following variables as the most important predictors (from most to least important): thigh circumference, SAT, fibrinogen, hip circumference, and red blood cells (RBC), while other independent variables were excluded from the final model (Table 2).

\section{Lifestyle and dietary habits}

Participants that preferred salty food had higher chemerin $(163 \pm 46$ vs. $136 \pm 40 \mathrm{ng} / \mathrm{mL}, \mathrm{p}=0.045)$ and fibrinogen $(3.15 \pm 0.66$ vs. $2.85 \pm 0.40 \mathrm{mg} / \mathrm{d}, \mathrm{p}=0.05)$ levels. The subjects considering nutritional facts to be the most important factor when buying food had lower chemerin than those who found flavor $(\mathrm{p}=0.029)$ and simplicity of preparation $(\mathrm{p}=0.005)$ to be most important. Study participants that smoked (37.3\%) had higher chemerin serum levels compared to those who 

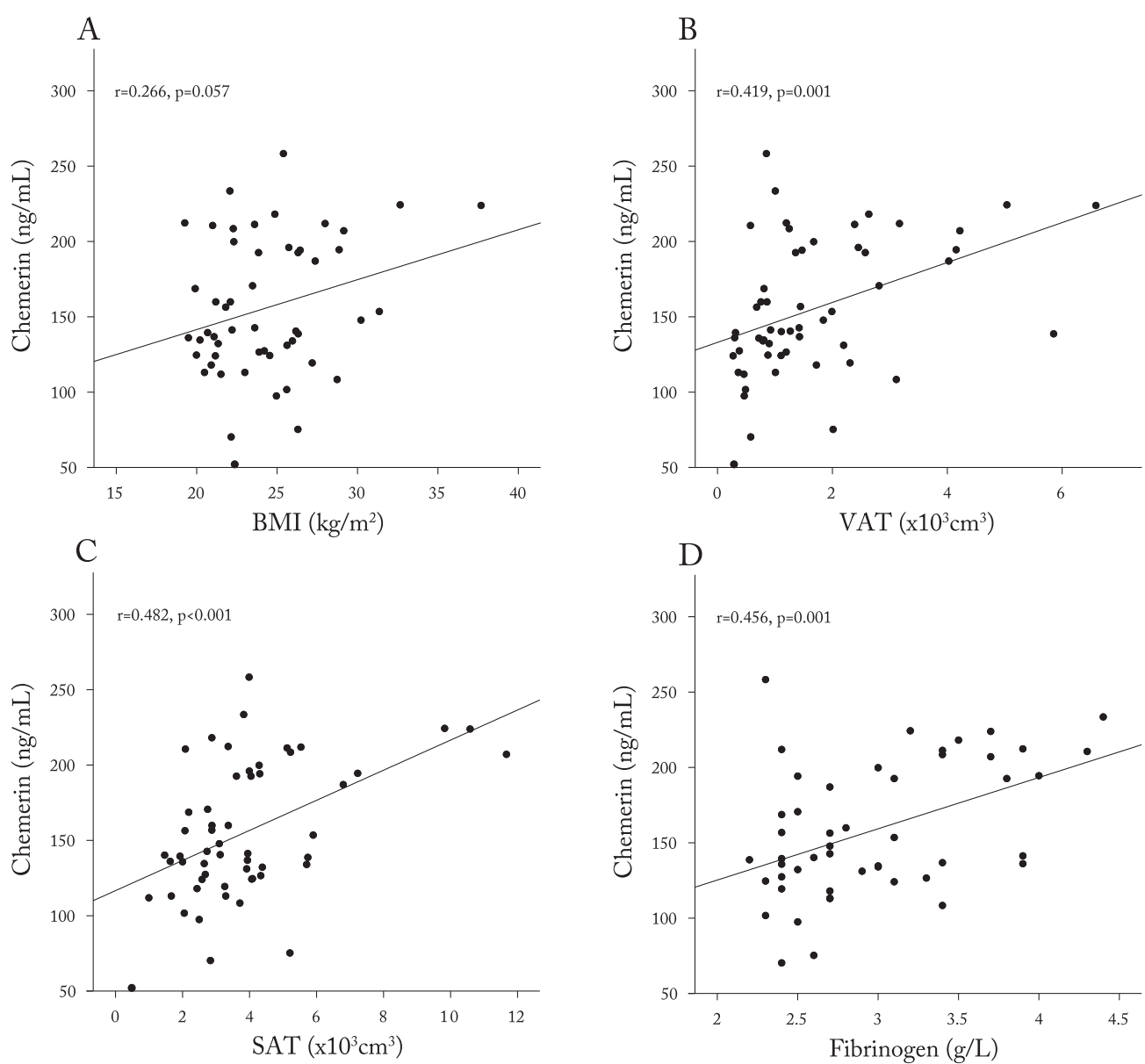

D
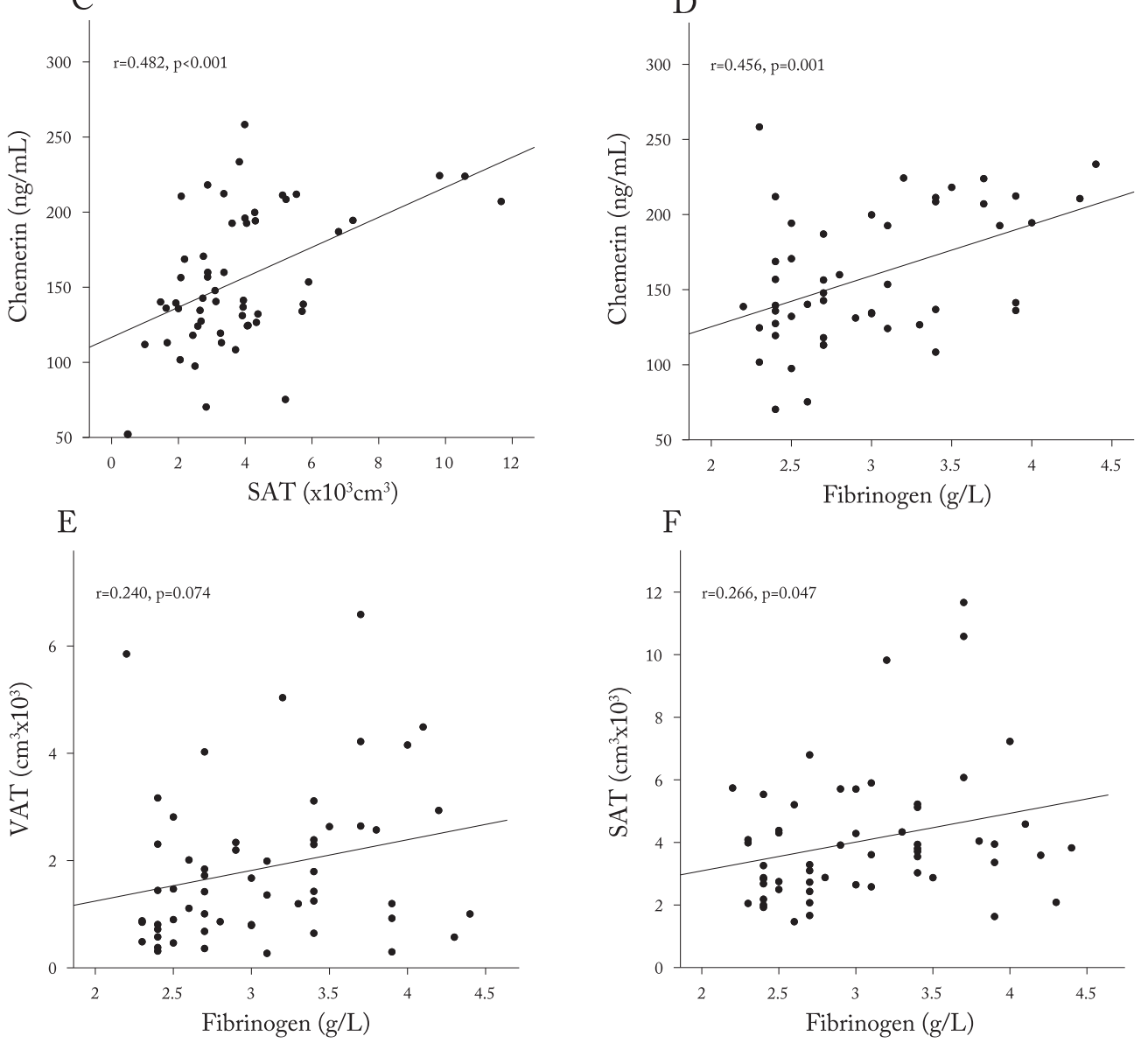

Fig. 1. Correlations of blood chemerin levels with abdominal adipose tissue volumes, anthropometric measures and blood parameters.

BMI (A), as well as other classical anthropometric measures, except for waist circumference and subscapular skinfold thickness, did not correlate with serum chemerin. MRI measured volumes of abdominal visceral (B) and subcutaneous (C) adipose tissue had a moderate positive correlation with serum chemerin. Chemerin and blood fibrinogen levels (D) showed moderately strong positive correlation. Fibrinogen levels did not correlate with abdominal visceral adipose tissue volume (E), but it showed a weak positive correlation with abdominal subcutaneous adipose tissue volume $(\mathrm{F})$.

$\mathrm{BMI}=$ body mass index VAT $=$ visceral adipose tissue; $\mathrm{SAT}=$ subcutaneous adipose tissue 
Table 2. Stepwise forward regression model for chemerin serum level prediction with MRI measured adipose tissue volumes, anthropometric measures, complete blood count and fibrinogen levels as independent predictors - final model independent variables controlled for age and sex, which are the most important predictors of chemerin serum levels

\begin{tabular}{|l|l|l|l|l|}
\hline Independent predictor & Coefficient & $\mathrm{p}$ & \multicolumn{3}{|l|}{ 95\% Confidence interval } \\
& & & Lower & Upper \\
\hline Thigh circumference $(\mathrm{cm})$ & -7.256 & 0.001 & -11.241 & -3.270 \\
Subcutaneous adipose tissue $(\mathrm{mL})$ & 0.011 & 0.001 & 0.005 & 0.018 \\
Fibrinogen $(\mathrm{g} / \mathrm{L})$ & 31.284 & 0.002 & 12.556 & 50.012 \\
Hip circumference $(\mathrm{cm})$ & 2.340 & 0.028 & 0.269 & 4.410 \\
Red blood cells $\left(\mathrm{x} 10^{12} / \mathrm{L}\right)$ & 23.428 & 0.044 & 0.709 & 46.148 \\
Intercept & -159.536 & 0.248 & -433.408 & 114.835 \\
\hline
\end{tabular}

did not smoke $(172 \pm 40$ vs. $144 \pm 40 \mathrm{ng} / \mathrm{mL}, \mathrm{p}=0.02)$. Participants who consumed alcohol on a regular basis (87\%; at least 3 times or more a month) had similar chemerin serum levels as their counterparts who did not consume alcohol $(\mathrm{p}=0.424)$. Additional stratification of participants by alcohol consumption rate did not show any differences in chemerin serum levels. Furthermore, study participants that exhibited binge drinking behavior (31.3\%) did not differ in chemerin serum levels $(149 \pm 42$ vs. $175 \pm 55 \mathrm{ng} / \mathrm{mL}, \mathrm{p}=0.123)$.

Furthermore, those who considered nutritional facts most important had less VAT $(\mathrm{p}=0.048)$ and SAT $(\mathrm{p}=0.040)$ than those who considered price as the main criterion whether to purchase the product. Participants who had breakfast more often (6-7 times a week) had less SAT compared to those who had breakfast less often (3-5 times a week) or not at all ( $\mathrm{p}=0.018$ and $\mathrm{p}=0.028$, respectively). There was also a difference between the groups with different breakfast habits in hip circumference and thigh circumference $(\mathrm{p}=0.058$ and $\mathrm{p}=0.032$, respectively). Also, participants who frequently ate small meals (snacks) several times a week or every day, had smaller WC ( $\mathrm{p}=0.037$ and $\mathrm{p}=0.021$, respectively) and thigh circumference $(\mathrm{p}=0.009$ and $\mathrm{p}=0.053$, respectively) than those who snacked seldom or never.

Participants who preferred high-fat dairy products had a higher VAT/SAT ratio than those taking medium- or low-fat dairy products $(\mathrm{p}=0.040$ and $\mathrm{p}=0.020$, respectively). People who were choosing food for themselves had lower thigh circumference than those whose food was chosen by their partner or family $(\mathrm{p}=0.036$ and $\mathrm{p}=0.013$, respectively). Participants con- suming olive oil regularly (compared to those using it occasionally or never) had greater triceps skinfold thickness ( $\mathrm{p}=0.001$ and $\mathrm{p}=0.004$, respectively) and SST ( $p=0.019$ and $p=0.003$, respectively). People consuming chocolate more than once a week had lower mean arterial pressure than people enjoying chocolate 1-4 times per month or less than once a month $(\mathrm{p}=0.040$ and $\mathrm{p}=0.004$, respectively).

\section{Discussion}

Chemerin is suggested as a biomarker of visceral adiposity and associated inflammatory process ${ }^{21}$. A recent study by Zylla et al. was the first to use MRI to assess volumes of total abdominal AT and chemerin. In line with our results, they established that both SAT and VAT were positively, mutually independently, associated with chemerin ${ }^{21}$. Due to the suggested role of chemerin as a predictor and risk factor for the development of metabolic syndrome and atherosclerotic process $^{21}$, it would be valuable to identify individuals at risk through low-cost measures such as classical anthropometric measures. Similar to our results, Zylla et al. ${ }^{21}$ clearly showed that chemerin increased steadily with increasing WC. Other inexpensive anthropometric measures such as triceps skinfold thickness and SST might also be of interest. Herein, we presented correlation of chemerin with SST that has not been established before. SST is a seldom used anthropometric parameter and is usually considered as a measure of truncal SAT ${ }^{25}$. Interestingly, SST was found to be the only valuable classical anthropometric measure which distinguished between transient and persistent 
impaired glucose tolerance ${ }^{26}$. Also, Savastano et al. showed that SST was the adiposity measure with the strongest negative association with blood level of insulin-like growth factor-I binding protein 1 , known to be altered inversely proportionally to the degree of visceral adiposity ${ }^{27,28}$. On the contrary, a study by Vasan $e t$ al. implied that abdominal skinfold rather than SST was associated with elevated blood glucose ${ }^{29}$. Nevertheless, it would be interesting to include SST in future studies aimed to assess factor clustering in metabolic and atherosclerotic phenotypes (i.e. disturbances in glucose, insulin and blood lipid regulation).

Not surprisingly, chemerin showed stronger correlation with MRI-assessed volumes of SAT and VAT than with the traditional anthropometric measures. On the other hand, regression analysis showed that, besides SAT, a 'classical' thigh circumference (a measure of SAT) was the most important predictor of chemerin level. A potential explanation why VAT did not emerge as a predictor of chemerin level is a modest sample size and rigorous controlling in the forward stepwise regression model. Additionally, although chemerin was clearly associated with visceral obese phenotypes, expression of chemerin mRNA in SAT and VAT did not differ in healthy, lean (BMI $<25 \mathrm{~kg} /$ $\mathrm{m}^{2}$ ) adults 9 . It is important to stress that absolute body volume of SAT is greater in both sexes ${ }^{30}$. With common single L4/L5 slice approach the results are skewed and miss much of the diversity of human body fat distribution. Although we assessed the majority of body VAT, unembraced SAT is also hormonally active tissue, where classical anthropometric measures ensure an insight into its quantity in other body regions.

Solely reducing BMI after bariatric surgery showed reduction of chemerin in a follow-up study9. Alternatively, after a 12-week exercise program, chemerin levels decreased without change in BMI. The exercise did, however, increase insulin sensitivity and decreased inflammatory activity (as assessed by CRP) ${ }^{9}$. Several studies $^{31-33}$ also showed that blood chemerin decreased after exercise and dietary interventions (calorie restriction and education), but did not investigate separately the effects of dietary habits. An interesting study by Khoo et al. on obese men after similar daily negative energy balance for 24 weeks, either through exercise regimen or through diet-intervention, showed similar decrease in weight and WC, but greater reduction of fat mass, chemerin and CRP in the exercise group.
Additionally, only exercising participants showed increased levels of the 'good' adipokine, adiponectin ${ }^{34}$. We showed that higher chemerin levels were present in healthy subjects who preferred salty food and those who primarily were thinking of simplicity of preparation or taste while buying food, as opposed to subjects whose primary concern was nutritive value regardless of their BMI. Such association between chemerin and dietary habits has not been documented earlier and increased sodium intake is associated with several morbidities. Although all our subjects were healthy, these data fit into the 'healthy lifestyle picture' of the population with lower chemerin. It is alluring to hypothesize that long-term effects of different adverse environmental factors might be partially mediated through chemerin, i.e. through long-term, silent 'inflammation excess'.

Obesity is characterized by increased levels of chemerin and fibrinogen ${ }^{2,35}$. Our study confirmed the association between chemerin and fibrinogen levels in a healthy population ${ }^{21,36}$. We still lack an explanation for the association, but we can conjecture that chronic inflammation in hypertrophic AT might underlie increases in the blood levels of both parameters. Nevertheless, as both fibrinogen and chemerin have been established as independent factors associated with the development of atherosclerosis, even in healthy subjects, the possible risk of developing cardiovascular diseases should be noted ${ }^{36,37}$.

The study by Chakaroun et al. offered a valuable insight into chemerin production; mRNA expression in omental (VAT) and SAT was similar in both depots in lean and obese (but higher in obese), and higher in VAT than in SAT of diabetic subjects ${ }^{9}$. Therefore, both AT depots are important producers of chemerin. Furthermore, it should be kept in mind that AT is not a single-cell type tissue and different expression profiles of cells within AT might explain discrepancies in the results from mRNA-based studies of VAT and SAT ${ }^{9,20}$.

It should not be forgotten that chemerin is not produced only in AT; the pancreas, liver and lungs are suggested to be greater sources ${ }^{14}$. Interestingly, in mice, chemerin was directly involved in local inflammatory response following exposure to cigarette smoke ${ }^{38}$. Information on environmental effects on chemerin levels is rather scant. Boyuk et al. report that chronic obstructive pulmonary disease patients with a history of smoking had higher chemerin than control (never- 
smokers) group ${ }^{39}$. Herenius et al. established 'a trend towards higher levels of chemerin in current smokers than in non-smokers' among patients with rheumatoid arthritis ${ }^{40}$. We showed that even in healthy population chemerin was higher among smokers. These results fit into the paradigm of unhealthy lifestyle choices leading to atherosclerosis and cardiovascular disease.

Data on the effects of alcohol intake on chemerin are limited. Chronic heavy drinking ( $>48 \mathrm{~g} / \mathrm{d})$ increased chemerin, whereas a study on rats suggested that elevated chemerin mostly reflected increased production in hypertrophic VAT ${ }^{41}$. In line with this study, in our group of mostly non-drinkers and occasional alcohol consumers, we did not establish any such association.

In conclusion, adipose tissue volumes of abdominal region moderately positively correlated with serum chemerin levels, while SAT volume, along with thigh circumference (anthropometric marker of SAT) was a more important predictor of serum chemerin levels than VAT after controlling for gender, age and BMI. Additionally, hip circumference was also shown to be an important predictor of serum chemerin levels. Furthermore, our results imply that dietary habits and lifestyle choices such as smoking, salt preference, healthy and 'slow' food, may influence blood chemerin levels independently of AT volumes. Finally, this study points in the direction of abdominal SAT and its relative contribution compared to VAT, as one of the major sources of chemerin, which might be a piece of puzzle underlying normal-weight obesity and metabolic syndrome.

\section{References}

1. Adams KF, Schatzkin A, Harris TB, Kipnis V, Mouw T, Ballard-Barbash R, et al. Overweight, obesity, and mortality in a large prospective cohort of persons 50 to 71 years old. N Engl J Med. 2006;355(8):763-78. DOI: 10.1056/NEJMoa055643

2. Cottam DR, Mattar SG, Barinas-Mitchell E, Eid G, Kuller L, Kelley DE, et al. The chronic inflammatory hypothesis for the morbidity associated with morbid obesity: implications and effects of weight loss. Obes Surg. 2004;14(5):589-600. DOI: 10.1381/096089204323093345

3. Matsuzawa Y, Shimomura I, Kihara S, Funahashi T. Importance of adipocytokines in obesity-related diseases. Horm Res. 2004;60(Supp1 3):56-9. DOI: 10.1159/000074502

4. Weigert J, Neumeier M, Wanninger J, Filarsky M, Bauer S, Wiest $\mathrm{R}$, et al. Systemic chemerin is related to inflammation rather than obesity in type 2 diabetes. Clin Endocrinol. 2010; 72(3):342-8.

5. Ferland DJ,Watts SW. Chemerin: a comprehensive review elucidating the need for cardiovascular research. Pharmacol Res. 2015;99:351-61. DOI: 10.1016/j.phrs.2015.07.018

6. Bozaoglu K, Bolton K, McMillan J, Zimmet P, Jowett J, Collier $\mathrm{G}$, et al. Chemerin is a novel adipokine associated with obesity and metabolic syndrome. Endocrinology. 2007;148(10): 4687-94. DOI: 10.1210/en.2007-0175

7. Ernst MC, Sinal CJ. Chemerin: at the crossroads of inflammation and obesity. Trends Endocrinol Metab. 2010;21(11): 660-7. DOI: 10.1016/j.tem.2010.08.001

8. Mattern A, Zellmann T, Beck-Sickinger AG. Processing, signaling, and physiological function of chemerin. IUBMB Life. 2014;66(1):19-26. DOI: 10.1002/iub.1242

9. Chakaroun R, Raschpichler M, Klöting N, Oberbach A, Flehmig G, Kern M, et al. Effects of weight loss and exercise on chemerin serum concentrations and adipose tissue expression in human obesity. Metabolism. 2012;61(5):706-14. DOI: 10.1016/j.metabol.2011.10.008

10. Chamberland JP, Berman RL, Aronis KN, Mantzoros CS. Chemerin is expressed mainly in pancreas and liver, is regulated by energy deprivation, and lacks day/night variation in humans. Eur J Endocrinol. 2013;169(4):453-62.

DOI: 10.1530/EJE-13-0098

11. Muruganandan S, Parlee SD, Rourke JL, Ernst MC, Goralski $\mathrm{KB}$, Sinal CJ. Chemerin, a novel peroxisome proliferator-activated receptor $\gamma(\operatorname{PPAR} \gamma)$ target gene that promotes mesenchymal stem cell adipogenesis. J Biol Chem. 2011;286(27): 23982-95. DOI: 10.1074/jbc.M111.220491

12. Roh S-G, Song S-H, Choi K-C, Katoh K, Wittamer V, Parmentier M, et al. Chemerin - a new adipokine that modulates adipogenesis via its own receptor. Biochem Biophys Res Commun. 2007;362(4):1013-8. DOI: 10.1016/j.bbrc.2007.08.104

13. Goralski KB, McCarthy TC, Hanniman EA, Zabel BA, Butcher EC, Parlee SD, et al. Chemerin, a novel adipokine that regulates adipogenesis and adipocyte metabolism. J Biol Chem. 2007;282(38):28175-88. DOI: 10.1074/jbc.M700793200

14. Bozaoglu K, Segal D, Shields KA, Cummings N, Curran JE, Comuzzie AG, et al. Chemerin is associated with metabolic syndrome phenotypes in a Mexican-American population. J Clin Endocrinol Metab. 2009;94(8):3085-8.

DOI: $10.1210 /$ jc.2008-1833

15. Weisberg SP, McCann D, Desai M, Rosenbaum M, Leibel RL, Ferrante AW. Obesity is associated with macrophage accumulation in adipose tissue. J Clin Investig. 2003;112(12): 1796-808. DOI: 10.1172/JCI19246

16. Wajchenberg BL. Subcutaneous and visceral adipose tissue: their relation to the metabolic syndrome. Endocr Rev. 2000; 21(6):697-738. DOI: 10.1210/edrv.21.6.0415

17. Ibrahim MM. Subcutaneous and visceral adipose tissue: structural and functional differences. Obes Rev. 2010;11(1):11-8. DOI: 10.1111/j.1467-789X.2009.00623.x 
18. Fox CS, Massaro JM, Hoffmann U, Pou KM, Maurovich-Horvat $\mathrm{P}$, Liu C-Y, et al. Abdominal visceral and subcutaneous adipose tissue compartments. Circulation. 2007;116(1):39-48. DOI: $10.1161 /$ CIRCULATIONAHA.106.675355

19. Alfadda AA, Sallam RM, Chishti MA, Moustafa AS, Fatma S, Alomaim WS, et al. Differential patterns of serum concentration and adipose tissue expression of chemerin in obesity: adipose depot specificity and gender dimorphism. Mol Cells. 2012 Jun 30;33(6):591-6. DOI: 10.1007/s10059-012-0012-7

20. Sledzinski T, Korczynska J, Hallmann A, Kaska L, ProczkoMarkuszewska M, Stefaniak T, et al. The increase of serum chemerin concentration is mainly associated with the increase of body mass index in obese, non-diabetic subjects. J Endocrinol Investig. 2013;36(6):428-34. DOI: 10.3275/8770

21. Zylla S, Pietzner M, Kühn JP, Völzke H, Dörr M, Nauck M, et al. Serum chemerin is associated with inflammatory and metabolic parameters-results of a population-based study. Obesity (Silver Spring). 2017 Feb;25(2):468-75.

DOI: $10.1002 /$ oby.21735.

22. Srdić B, Stokić E, Polzović A, Babović SS. Abdominal adipose tissue: significance and methods of detection. Med Pregl. 2005;58(5-6):258-64.

23. Kamel EG, McNeill G, Wijk MC. Usefulness of anthropometry and DXA in predicting intra-abdominal fat in obese men and women. Obes Res. 2000;8(1):36-42.

DOI: $10.1038 /$ oby.2000.6

24. Shin HY, Lee DC, Chu SH, Jeon JY, Lee MK, Im JA, et al. Chemerin levels are positively correlated with abdominal visceral fat accumulation. Clin Endocrinol (Oxf). 2012;77(1): 47-50. DOI: 10.1111/j.1365-2265.2011.04217.x

25. Zhang M, Hu T, Zhang S, Zhou L. Associations of different adipose tissue depots with insulin resistance: a systematic review and meta-analysis of observational studies. Sci Rep. 2014;5:18495. DOI: 10.1038/srep18495

26. Mensink M, Feskens E, Kruijshoop M, De Bruin T, Saris W, Blaak E. Subscapular skinfold thickness distinguishes between transient and persistent impaired glucose tolerance: Study on Lifestyle-Intervention and Impaired Glucose Tolerance Maastricht (SLIM). Diabet Med. 2003;20(7):552-7.

27. Parekh N, Roberts CB, Vadiveloo M, Puvananayagam T, Albu JB, Lu-Yao GL. Lifestyle, anthropometric, and obesity-related physiologic determinants of insulin-like growth factor- 1 in the Third National Health and Nutrition Examination Survey (1988-1994). Ann Epidemiol. 2010;20(3):182-93.

DOI: $10.1016 /$ j.annepidem.2009.11.008

28. Savastano S, Barbato A, Di Somma C, Guida B, Pizza G, Barrea $\mathrm{L}$, et al. Beyond waist circumference in an adult male population of southern Italy: is there any role for subscapular skinfold thickness in the relationship between insulin-like growth factor-I system and metabolic parameters? J Endocrinol Investig. 2012;35:925-9.

29. Vasan S, Thomas N, Christopher S, Geethanjali F, Paul T, Sanjeevi C. Anthropometric measurements for the prediction of the metabolic syndrome: a cross-sectional study on adolescents and young adults from southern india. Heart Asia. 2011; 3(1):2-7. DOI: 10.1136/ha.2009.001735

30. Müller HP, Raudies F, Unrath A, Neumann H, Ludolph AC, Kassubek J. Quantification of human body fat tissue percentage by MRI. NMR Biomed. 2011;24(1):17-24.

DOI: $10.1002 / \mathrm{nbm} .1549$

31. Kim SH, Lee SH, Ahn KY, Lee DH, Suh YJ, Cho SG, et al. Effect of lifestyle modification on serum chemerin concentration and its association with insulin sensitivity in overweight and obese adults with type 2 diabetes. Clin Endocrinol (Oxf). 2014;80(6):825-33. DOI: 10.1111/cen.12249

32. Lee MK, Chu SH, Lee DC, An KY, Park J-H, Kim DI, et al. The association between chemerin and homeostasis assessment of insulin resistance at baseline and after weight reduction via lifestyle modifications in young obese adults. Clin Chim Acta. 2013;421:109-15. DOI: 10.1016/j.cca.2013.02.017

33. Stefanov T, Blüher M, Vekova A, Bonova I, Tzvetkov S, Kurktschiev D, et al. Circulating chemerin decreases in response to a combined strength and endurance training. Endocrine. 2014;45(3):382-91. DOI: 10.1007/s12020-013-0003-2

34. Khoo J, Dhamodaran S, Chen D-D, Yap S-Y, Chen RY-T, Tian $\mathrm{RH}-\mathrm{H}$. Exercise-induced weight loss is more effective than dieting for improving adipokine profile, insulin resistance, and inflammation in obese men. Int J Sport Nutr Exerc Metab. 2015;25(6):566-75. DOI: 10.1123/ijsnem.2015-0025

35. Sola E, Vaya A, Simo M, Hernandez-Mijares A, Morillas C, Espana F, et al. Fibrinogen, plasma viscosity and blood viscosity in obesity. Relationship with insulin resistance. Clin Hemorheol Microcirc. 2007;37(4):309-18.

36. Han J, Kim SH, Suh YJ, Lim H, Shin H, Cho SG, et al. Serum chemerin levels are associated with abdominal visceral fat in type 2 diabetes. J Korean Med Sci. 2016;31(6):924-31. DOI: 10.3346/jkms.2016.31.6.924

37. Yan Q, Zhang Y, Hong J, Gu W, Dai M, Shi J, et al. The association of serum chemerin level with risk of coronary artery disease in Chinese adults. Endocrine. 2012;41(2):281-8. DOI: 10.1007/s12020-011-9550-6

38. Demoor T, Bracke KR, Dupont LL, Plantinga M, Bondue B, Roy M-O, et al. The role of ChemR23 in the induction and resolution of cigarette smoke-induced inflammation. J Immunol. 2011;186(9):5457-67. DOI: 10.4049/jimmunol.1003862

39. Boyuk B, Guzel EC, Atalay H, Guzel S, Mutlu LC, Kucukyalçin V. Relationship between plasma chemerin levels and disease severity in COPD patients. Clin Respir J. 2015;9(4): 468-74.

40. Herenius MM, Oliveira AS, Wijbrandts CA, Gerlag DM, Tak PP, Lebre MC. Anti-TNF therapy reduces serum levels of chemerin in rheumatoid arthritis: a new mechanism by which anti-TNF might reduce inflammation. PLoS One. 2013;8(2): e57802. DOI: 10.1371/journal.pone.0057802

41. Ren R-Z, Zhang X, Xu J, Zhang H-Q, Yu C-X, Cao M-F, et al. Chronic ethanol consumption increases the levels of chemerin in the serum and adipose tissue of humans and rats. Acta Pharmacol Sin. 2012;33(5):652-9. DOI: 10.1038/aps.2012.11 


\title{
Sažetak
}

\section{RAZINA KEMERINA U KRVI JE POVEZANA S VOLUMENIMA TRBUŠNOG MASNOG TKIVA IZMJERENIMA POMOĆU MAGNETSKE REZONANCIJE I ČIMBENICIMA STILA ŽIVOTA}

\author{
T. Salha, D. Andrijervić, Z. Vrselja, V. Šerić, R. Radić i G. Curic
}

Pretilost je stanje obilježeno kroničnom upalom niskog intenziteta u kojoj citokin kemerin, imunometabolički modulator, ima važnu ulogu. Cilj studije je bio u zdrave populacije istražiti odnose između serumskih razina kemerina, životnih navika i magnetnom rezonancijom (MR) utvrđenih volumena abdominalnog visceralnog (VMT) i subkutanog (SMT) masnog tkiva za koje je pokazano da imaju drukčije citokinske ekspresijske profile. U studiju su bila uključena 73 zdrava sudionika koji su odgovorili na upitnik o životnim navikama, potom su izmjerene njihove antropometrijske mjere te utvrđeni volumeni abdominalne regije VMT i SMT pomoću MR. U svih ispitanika je napravljena kompletna krvna slika uz procjenu serumskih razina kemerina i fibrinogena. Učinjeni su regresijski modeli za procjenu serumskog kemerina uz kontrolu prema spolu, dobi i antropometrijskim mjerama. Serumska vrijednost kemerina iznosila je 141 (125-195) ng/mL. Serumski kemerin srednje jako je korelirao s volumenom SMT i VMT. Dva najvažnija prediktora serumskog kemerina bili su volumen SMT i opseg natkoljnice. Nezavisno od volumetrijskih mjerenja, pušenje, slana hrana i preferiranje okusa/jednostavne prehrane imali su utjecaja na serumski kemerin. Serumski kemerin jače je povezan s volumenom SMT nego VMT, dok nezavisno od volumena masnog tkiva određene životne navike utječu na razine serumskog kemerina.

Ključne riječi: Pretilost; Citokini - krv; Magnetska rezonancija, snimanje; Fibrinogen; Abdominalno salo; Adipokini; Intraabdominalno salo; Način života; Pušenje 